Acta vet. scand. $1960,1,324-346$.

From the Department of Chemistry and the Department of Bacteriology, The Royal Veterinary College, Stockholm.

\title{
SPREADING ACTIVITY IN BOVINE UDDER EXTRACT
}

By

W. Thorsell and B. K. Nordberg.

The presence of a spreading factor in mammary tissue of albino rats and mice, guinea pigs, and rabbits was reported by Elliott et al. in 1953 (7). This spreading factor, it was suggested, was concerned with the infiltration of connective tissue by glandular tissue.

It is probable that a similar factor or factors are present in the udder tissue of cattle and that the amount varies with the stage of pregnancy. The experiments to be described here were undertaken to ascertain whether udder extract from cattle-UEdisplays a spreading activity-SA-, whether this SA is associated with a species-specific or a non-species-specific substance, and whether or not this SA varies at different stages of pregnancy. Furthermore, studies have been made of the effect of UE on vascular permeability- $\mathrm{VP}$ - and its capacity to lyse connective tissue-TL_. Attempts have been made to isolate and purify UE. The effects of UE on microorganisms have also been studied.

\section{PRELIMINARY INVESTIGATION TO SHOW SPREADING ACTIVITY OF UDDER EXTRACT}

\section{A:1 Rabbit skin.}

The extracts were prepared in the manner described by Elliott et al (7) from udder tissue obtained from healthy cows. Immediately after slaughter and after bloodvessels, lymphatic tissue and any milk present were removed, one to $25 \mathrm{~g}$ tissue from the peripheral glandular tissue of all quarters was taken and homo- 
genised in $0.1 \mathrm{M}$ acetate buffer, $\mathrm{pH}$ 6.0, containing $0.15 \mathrm{M}$ sodium chloride. After centrifugation, $\mathrm{SA}$ was tested in the following manner. To $0.2 \mathrm{ml}$ extract containing between $1 \times 10^{-3}$ to $6 \times 10^{-3} \mathrm{~g}$ dry matter was added $0.1 \mathrm{ml} 1$ per cent Evan's blue in acetate buffer. This mixture was injected intradermally along the back of a male white rabbit weighing about $2.5 \mathrm{~kg}$ and which had been shaved the previous day. The injections were performed at a rate of about $0.05 \mathrm{ml} / 5 \mathrm{sec}$ on the right side about $2 \mathrm{~cm}$ lateral to the summits of the dorsal vertebral processes. The first injection was made on the neck, and the second at the level of the last ribs. Immediately after injection and after 15, 30, 60, 120, and 240 minutes, the greatest and the least dimension of the

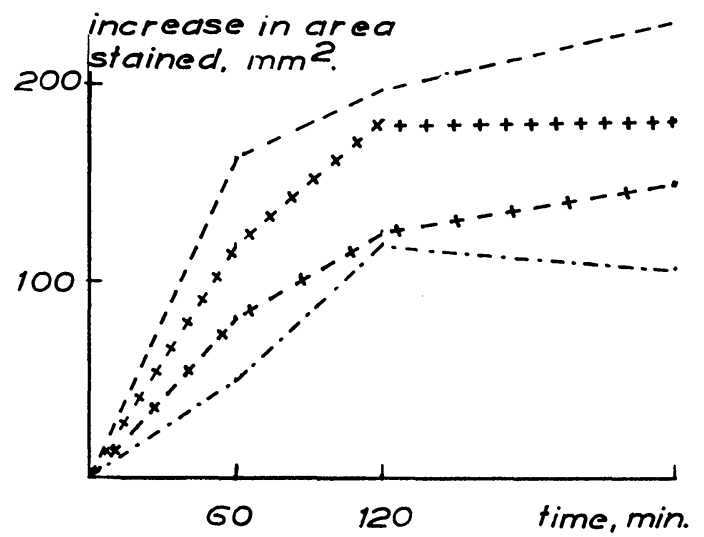

F i g. 1. Spreading activity of udder extract in rabbit skin.

Symbols: - _ - UE 26; - - - - UE 26, heated; + + + UE 26;

-+ - buffer solution.

stained area were measured. Calipers with an accuracy of $0.1 \mathrm{~mm}$ were used for these measurements. The area stained after 15, 30, 60,120 , and 240 minutes was calculated by substraction of the initial value. As a control both $\mathrm{UE}$ heated at $100^{\circ} \mathrm{C}$ for $30 \mathrm{minu}-$ tes and acetate buffer were used, injected into the left side. The technique, in short, is that described in papers of Elliott et al. (7), Madinaveitia (20) and Hayes (13). All experiments were carried out at $20^{\circ} \mathrm{C}$ on two animals and the injection sites for the control substances were alternated. All substances injected were free from bacterial contamination according to methods described in a manual of the Society of American Bacteriologists (32). 
SA for an UE sample, UE no. 26 in table 1, is illustrated in figs. 1 and 2 . This extract contained $0.0214 \mathrm{~g}$ dry matter per $\mathrm{ml}$.

It is apparent from the figures that UE 26 has a SA in rabbit skin. SA is abolished by heating at $100^{\circ} \mathrm{C}$ for 30 minutes.. Other UE samples tested have displayed much the same properties as UE 26.

\section{A :2 Cattle skin.}

These experiments were carried out in the manner described for the rabbit. The volume injected was greater, $0.33 \mathrm{ml}$. UE

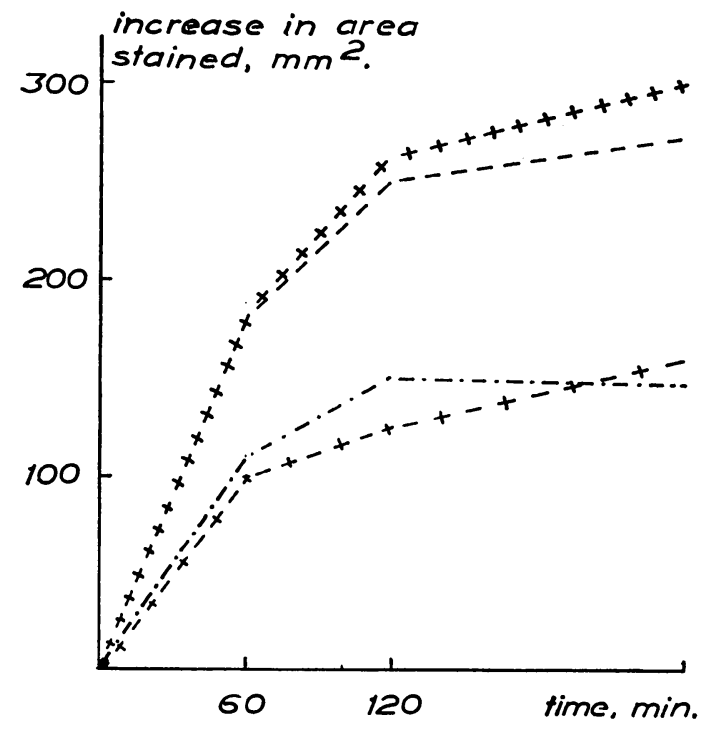

F 1 g. 2. Spreading activity of udder extract in rabbit skin. Symbols compare fig. 1 .

containing between $2 \times 10^{-3}$ and $10 \times 10^{-3} \mathrm{~g}$ dry matter and 0.17 ml 1 per cent Evan's blue. Two non-pregnant cows were used as experimental animals.

Figs. 3 and 4 represent SA for UE 19 and UE 21. The dry matter content of these extracts was 0.0186 and $0.0167 \mathrm{~g} / \mathrm{ml} \mathrm{re}-$ spectively.

As was the case for rabbit skin, UE 19 and UE 21 also displayed SA in cattle skin. The effect is clearly not species specific. This fact permitted the use of rabbits in further studies, partly for economy and partly to facilitate comparison with descriptions of spreading activity of other tissues (25). 


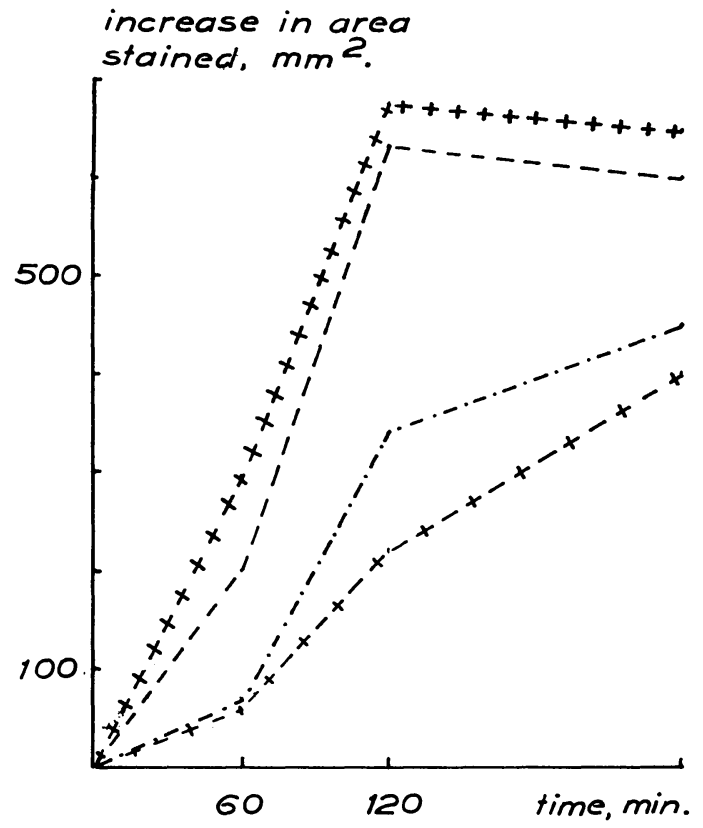

F i g. 3. Spreading activity of udder extract in cattle skin. Symbols compare fig. 1 .

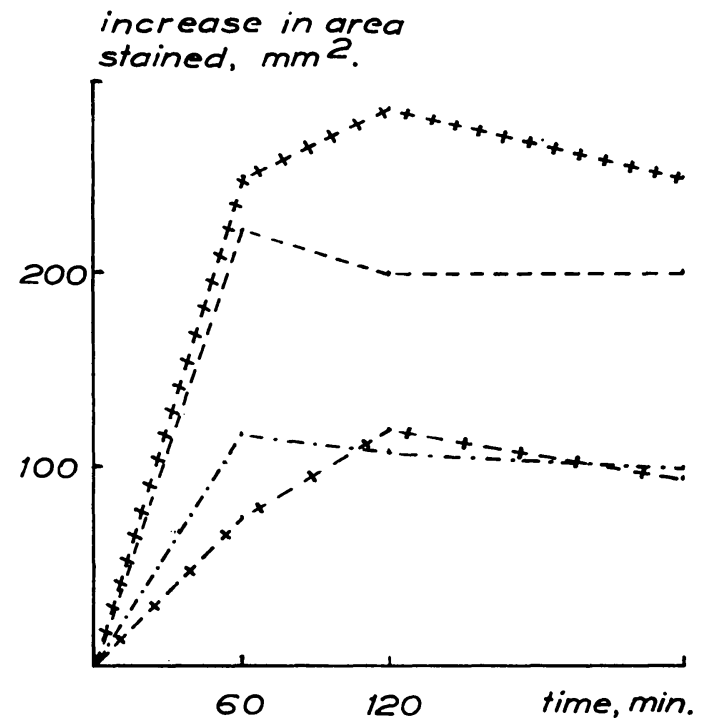

F i g. 4. Spreading activity of udder extract in cattle skin. Symbols compare fig. 1 . 
B. Spreading activity in udder extract from cows in different stages of pregnancy.

This section deals with the question of whether or not UE obtained from cattle in various stages of pregnancy exercises different degrees of SA as has been demonstrated by Elliott et al. (7) for small laboratory animals.

The technique described above was used.

Table 1 summarises the results obtained. The symbol + indicates an activity corresponding to those illustrated in figs. 1 and 2 for unheated extract. The symbol $\div$ has been used to designate SA of the same degree as was obtained for the controls, i. e. heated extract and buffer solution. Each result represents experiments on two animals. The dry matter content of the extracts has also been given.

According to table 1, UE obtained from both heifers and cows displays SA but this property seems suppressed in nonpregnant animals.

The UE obtained does not represent SA for the entire glandular tissue since only a small sample was taken. It can be assumed that those negative results which were obtained for the pregnant animals can be ascribed to the sampling technique. Elliott et al. (7), on the other hand, were able to utilise the entire glandular tissue from small laboratory animals for their investigations.

SA is apparently not directly proportional to the dry matter content.

\section{UDDER EXTRACT AND VASCULAR PERMEABILITY}

The intradermal spreading of Evan's blue produced by UE has been studied in order to ascertain whether or not this spreading is mediated through increased vascular permeability and the occurrence of oedema. This was done by observing the escape of an intravenously injected dye into the site of intradermal injection.

Male rabbits weighing about $2.5 \mathrm{~kg}$ and shaved the previous day were injected intradermally on the back with $0.2 \mathrm{ml} \mathrm{UE}$ and control substances-UE heated at $100^{\circ} \mathrm{C}$ for 30 minutes and acetate buffer at $\mathrm{pH} 6.0$-in $0.1 \mathrm{ml} 0.15 \mathrm{M}$ sodium chloride. These experiments were carried out in duplicate in the manner described above. From 2 to 4 hours later, 10 to $20 \mathrm{ml} 1$ per cent Evan's blue in $0.15 \mathrm{M}$ sodium chloride was injected into one of the ear 
Tab le 1.

SA in UE from cattle in different stages of pregnancy.

\begin{tabular}{|c|c|c|c|}
\hline UE no. & Foetal length $\mathrm{cm}$ & Dry matter $\mathrm{g} / \mathrm{ml}$ & SA \\
\hline 1 & 0.0 & 0.0097 & $\div$ \\
\hline 2 & 0.0 & 0.0065 & $\div$ \\
\hline 3 & 0.0 & 0.0058 & $\div$ \\
\hline 4 & 0.0 & 0.0071 & $\div$ \\
\hline 5 & 0.0 & 0.0065 & $\div$ \\
\hline 6 & 12.0 & 0.0094 & + \\
\hline 7 & 16.0 & 0.0126 & $\div$ \\
\hline 8 & 16.5 & 0.0073 & $\div$ \\
\hline 9 & 18.5 & 0.0110 & + \\
\hline 10 & 23.0 & 0.0167 & + \\
\hline 11 & 25.0 & 0.0322 & $\div$ \\
\hline 12 & 30.0 & 0.0106 & + \\
\hline 13 & 35.0 & 0.0150 & + \\
\hline 14 & 40.0 & 0.0113 & + \\
\hline 15 & 47.0 & 0.0268 & $\div$ \\
\hline 16 & 48.0 & 0.0205 & + \\
\hline 17 & 50.0 & 0.0127 & + \\
\hline 18 & 53.0 & 0.0231 & + \\
\hline 19 & 54.0 & 0.0186 & + \\
\hline 20 & 54.0 & 0.0151 & + \\
\hline 21 & 55.0 & 0.0167 & + \\
\hline 22 & 56.0 & 0.0186 & + \\
\hline 23 & 57.5 & 0.0285 & + \\
\hline 24 & 59.0 & 0.0186 & + \\
\hline 25 & 61.0 & 0.0220 & + \\
\hline 26 & 62.2 & 0.0214 & + \\
\hline 27 & 63.0 & 0.0207 & + \\
\hline 28 & 65.0 & 0.0131 & $\div$ \\
\hline 29 & 72.0 & 0.0236 & + \\
\hline 30 & 80.0 & 0.0227 & + \\
\hline 31 & 82.0 & 0.0214 & + \\
\hline 32 & 84.0 & 0.0214 & + \\
\hline 33 & 0.0 & 0.0066 & $\div$ \\
\hline 34 & 11.3 & 0.0068 & + \\
\hline 35 & 24.0 & 0.0074 & + \\
\hline 36 & 24.0 & 0.0071 & + \\
\hline 37 & 24.0 & 0.0067 & + \\
\hline 38 & 35.0 & 0.0062 & + \\
\hline 39 & 35.0 & 0.0088 & $\div$ \\
\hline 40 & 35.0 & 0.0075 & + \\
\hline 41 & 41.3 & 0.0086 & + \\
\hline 42 & 48.1 & 0.0143 & + \\
\hline 43 & 55.3 & 0.0061 & + \\
\hline 44 & 71.2 & 0.0072 & + \\
\hline
\end{tabular}

UE no. 1-32 from heifers. UE no. 33-44 from cows. 
Table 2.

Changes in VP compared with SA in UE from pregnant animals.

$\begin{array}{ccc}\text { UE no. } & \text { SA } & \text { VP } \\ 6 & + & + \\ 7 & \div & (+) \\ 8 & \div & \div \\ 9 & + & + \\ 10 & + & (+) \\ 11 & \div & + \\ 12 & + & + \\ 13 & + & + \\ 14 & + & + \\ 15 & \div & + \\ 16 & + & + \\ 17 & + & + \\ 18 & + & + \\ 19 & + & + \\ 20 & + & + \\ 21 & + & + \\ 22 & + & + \\ 23 & + & + \\ 24 & + & + \\ 25 & + & + \\ 26 & + & + \\ 27 & + & + \\ 28 & + & + \\ 29 & + & + \\ 30 & + & + \\ 31 & + & + \\ 32 & + & + \\ 41 & + & + \\ 42 & + & + \\ 43 & + & + \\ & + & +\end{array}$

veins. The injection sites on the back were observed during the 30 or 40 minutes after the administration of dye for the occurence of staining $(23,30)$.

The effect of UE on VP is given in table 2. For ease of reference this table also includes SA for Evan's blue. Escape of the intravenously administered Evan's blue into the site of intradermal injection is given as + , i. e. increased VP; $(+)$ signifies doubtful VP increase, and $\div$ a negative result.

It is apparent from the table that the majority of UE produce an increase in VP just as they increase the local spreading of Evan's blue. 


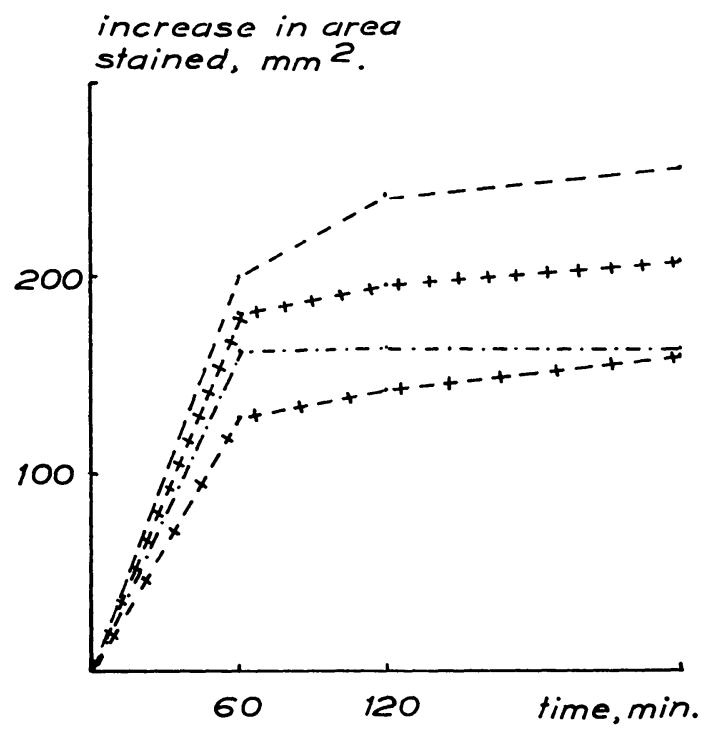

Fi g. 5. Spreading activity of udder extract in isolated rabbit skin. Symbols compare fig. 1.

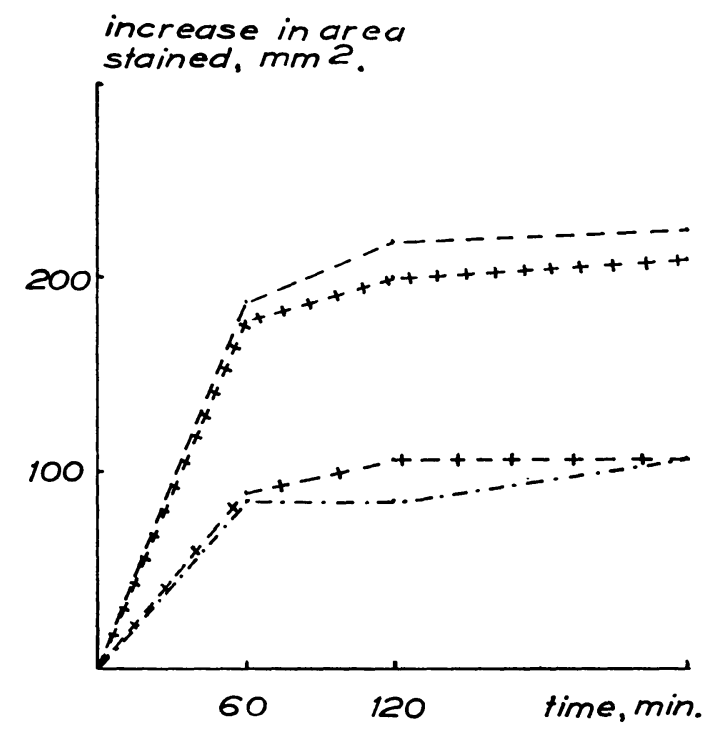

Fi g. 6. Spreading activity of udder extract in isolated rabbit skin. Symbols compare fig. 1 . 
The capacity of UE to influence VP may be associated with the presence or formation of low-molecular substances such as histamine, serotonin, and peptides, or of high-molecular substances such as proteins $(3,34)$. One attempt to demonstrate histamine in UE 32 by biological methods according to Glick (11) was unsuccessful. But the methods of Feldberg et al. (8) and Norton (27) no suggestion of a histamine-liberator could be detected in that extract.

\section{LYSIS OF CONNECTIVE TISSUE BY UDDER EXTRACT} Isolated rabbit skin.

Since the previous results gave no invariable correlation between SA and increase of VP another possible explanation for SA may be decrease of the resistance offered by connective tissue by lysis of its components with consequent ease of spreading for Evan's blue.

The skin of a male rabbit weighing about $2.5 \mathrm{~kg}$ and shaved the previous day was removed immediately after death and stretched over a board which had been covered with a towel. The towel was kept moist by means of distilled water. SA for UE was tested as described above. These experiments were carried out in duplicate at $37^{\circ} \mathrm{C}$ according to methods by Madinaveitia (21) and Mc Clean (22).

Figs. 5 and 6 contain the data for TL with UE 21.

Table 3 .

TL compared with SA and changes in VP for UE from pregnant cattle.

$\begin{array}{cccc}\text { UE nr. } & \text { SA } & \text { VP } & \text { TI } \\ 10 & + & (+) & + \\ 11 & \div & \div & \div \\ 12 & + & (+) & \div \\ 19 & + & + & + \\ 21 & + & + & + \\ 23 & + & + & \div \\ 24 & + & ++ & + \\ 25 & + & + & + \\ 26 & + & + & + \\ 29 & + & + & + \\ 30 & + & + & + \\ 31 & + & + & + \\ 41 & + & + & + \\ 42 & + & + & + \\ 43 & + & (+) & \end{array}$


TL is clearly associated with a substance or substances inactivated by heating at $100^{\circ} \mathrm{C}$ for 30 minutes.

TL for all tested UE samples from pregnant animals is given in table 3. A TL corresponding to that shown in figs. 5 and 6 for unheated UE is given as +. TL corresponding to that obtained for control substances-heated UE and buffer solution-is indicated as $\div$.

It can be seen from table 3 that the presumed TL is often associated with increase of VP. In some samples, however, SA is present but not VP or TL. From this it appears that at least one additional factor is involved. Inactivation of the UE samples during storage cannot be ignored.

\section{Connective tissue components.}

Several factors with spreading activity for dyes in skin have been described; some of these displayed catalytic properties, others not $(3,25,34,35)$. Since mammary gland tissue contains several enzymes (15), enzyme activity in UE might have some relationship with its SA for Evan's blue.

The capacity of the UE samples to hydrolyse various components of connective tissue (31) - cells, fibres, and ground substance-through the possible activity of enzymes- $\mathrm{E}$ - has been considered.

Hydrolysis of collagen.

Substrate was prepared from cattle skin in the manner described by Highberger (14) and Neumann et al. (26); the material, however, was not trypsinised. Of this collagen preparation, 98.6 per cent could be gelatinised.

E consisted of UE 43 (table 3 ) concentrated by centrifugation, dialysis, and evaporation to a small volume, UE 43 a.

Procedure for hydrolysis: To $0.5 \mathrm{~g}$ collagen were added 0.2

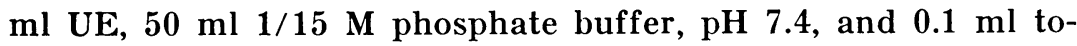
luene as a disinfectant. Experiments were carried out at $37^{\circ} \mathrm{C}$. After $0,4,24$, and 72 hours, $5 \mathrm{ml}$ aliqouts were centrifuged. The nitrogen content in $1 \mathrm{ml}$ solution was established by Kjeldahls method in Conway's modification (5).

Controls consisted of collagen and buffer solution, and $\mathrm{E}$ and buffer solution. The $\mathrm{pH}$ of the systems was checked before and after the experiments.

Results are expressed as the increase in soluble nitrogen. 
Hydrolysis of bovine udder homogenate (increase in soluble nitrogen).

A similar procedure was applied with 2 per cent w/v udder homogenate instead of 1 per cent w/v collagen. UE 26 (table 3) was used as $\mathrm{E}$.

Results are expressed as increase in soluble nitrogen.

Hydrolysis of serum proteins.

Cattle serum was used as substrate and UE 43 a as E.

Hydrolysis was studied at $37^{\circ} \mathrm{C}$ in the following manner. To $15 \mathrm{ml}$ serum were added $5 \mathrm{ml} 1 / 15 \mathrm{M}$ phosphate buffer, $\mathrm{pH}$ 7.4, $0.2 \mathrm{ml} \mathrm{UE}$, and $0.1 \mathrm{ml}$ toluene. After 0,4 , and 24 hours, $1 \mathrm{ml}$ aliquots were titrated with $0.01 \mathrm{M}$ ethanolic potassium hydroxide after the addition of ethanol and formaldehyde (4).

Serum and buffer solution, and $\mathrm{E}$ and buffer solution served as controls. pH of the systems was checked before and after the experiments.

Results are expressed as increase in titratable groups.

Hydrolysis of hyaluronic acid.

As substrate were utilised bovine cornea and synovial fluid, both obtained immediately after slaughter, and hyaluronic acid prepared from human umbilical cord by Meyer's method (24).

All substrates were employed as $0.3 \mathrm{per}$ cent $\mathrm{w} / \mathrm{v}$ solutions in $1 / 15 \mathrm{M}$ phosphate buffer, $\mathrm{pH} 6.0$ and 7.4 , containing $0.15 \mathrm{M}$ sodium chloride.

As $\mathrm{E}$ was used UE 43 a diluted 1:5 with the phosphate buffers.

To $3 \mathrm{ml}$ substrate in the viscometer were added $2 \mathrm{ml} \mathrm{E}$ at $37^{\circ} \mathrm{C}$. The flowtime was measured after $5,10,15,30,60,120$, and 240 minutes.

Substrate and buffer, and $\mathrm{E}$ and buffer served as controls. $\mathrm{pH}$ of the systems was checked before and after the experiments.

Results are expressed as reduction in viscosity-flowtime-.

Hydrolysis of chondroitin sulphuric acid.

Substrate consisted of 0.2 per cent w/v chondroitin sulphuric acid prepared from cattle cartilage in $1 / 15 \mathrm{M}$ phosphate buffer, $\mathrm{pH}$ 7.4, with and without the addition of $0.15 \mathrm{M}$ sodium chloride. UE 43 a diluted $1: 5$ in the buffer solutions served as $E$. 
To $10 \mathrm{ml}$ substrate were added $2 \mathrm{ml} \mathrm{E}$ and $0.1 \mathrm{ml}$ toluene. Reducing groups were determined after 0 and 24 hours in $5 \mathrm{ml}$ mixture by Somogyi's method (33).

Substrate and buffer, and $\mathrm{E}$ and buffer were used as controls. $\mathrm{pH}$ of the systems was checked before and after the experiments.

Results are expressed as increase in reducing groups.

Hydrolysis of bovine udder homogenate (increase in reducing groups).

Substrate consisted of 1 and 2 per cent w/v udder homogenate in buffer of the same type used in the experiments with chondroitin sulphuric acid.

E consisted of UE 26 diluted in the manner described under chondroitin sulphuric acid.

Results are expressed as increase in reducing groups.

Hydrolysis of fat.

a) Neutral fat.

Substrate consisted of olive oil p.a. and udder homogenate.

As $E$ was used UE 43 and UE 26.

To $2.5 \mathrm{~g}$ olive oil and udder homogenate respectively were added $2 \mathrm{ml}$ buffer solution, 1/15 $\mathrm{M}$ phosphate buffer $\mathrm{pH} 7.0$ and $1 \mathrm{M}$ ammonia-ammonium buffer $\mathrm{pH} 9.0,0.5 \mathrm{ml} 2$ per cent w/v calcium chloride solution, $0.5 \mathrm{ml} 3$ per cent $\mathrm{w} / \mathrm{v}$ albumin solution, and $10 \mathrm{ml} \mathrm{E}$ diluted 2:15 with buffer solution. The experiments were carried out at $37^{\circ}$ C. After 0 and 24 hours, the amount of acid groups was established by titration with ethanolic potassium hydroxide as described in Hawk-Oser-Summerson (12).

Substrate and buffer, and $\mathrm{E}$ and buffer served as controls. $\mathrm{pH}$ of the systems was checked at the beginning and at the end of the experiments.

Results are expressed as increase in titratable groups.

b) Phospholipids.

Substrate consisted of egg yolk, lecithin prepared by Pangborn's method (28), and bovine erythrocytes.

E consisted of UE 43 a diluted $1: 3$ with $1 / 15 \mathrm{M}$ phosphate buffer $\mathrm{pH} 7.4$ containing $0.15 \mathrm{M}$ sodium chloride.

The yolk of an egg was suspended in $100 \mathrm{ml}$ phosphate buf- 
fer. To $20 \mathrm{ml}$ of this suspension was added $0.2 \mathrm{ml} \mathrm{E}$. After 0,4 , and 24 hours, the increase in titratable groups was measured (2).

A suspension of $0.1 \mathrm{~g}$ lecithin in $5 \mathrm{ml}$ phosphate buffer was prepared, and to this was added $0.1 \mathrm{ml} \mathrm{E}$. After 0 and 6 hours, $1 \mathrm{ml}$ ethanol was mixed with $1 \mathrm{ml}$ of the suspension and boiled for 5 minutes. Of the clear supernatant was taken $0.01 \mathrm{ml}$ and placed on Whatman no. 1 paper for ascending chromatography according to Huenikens (16). Phosphomolybdic acid reagent was used as indicator (18).

In both instances controls were set up with substrate and buffer, and $\mathrm{E}$ and buffer. The $\mathrm{pH}$ of the systems was checked before and after the experiments.

The haemolysing effect of $\mathrm{E}$ was tested by placing $0.1 \mathrm{ml}$ on blood agar plates as described in the manual of the Society of American Bacteriologists (32).

The substrates tested-collagen, albumin, globulin, hyaluronic acid, chondroitin sulphuric acid, and neutral fat-were not hydrolysed in the presence of UE. When the effect of testicular hyaluronidase was compared with that of UE on rabbit skin, it could be shown that hyaluronidase displayed more rapid SA than UE (cf. UE 25). With phospholipids-egg yolk-as substrate, there was a slight increase in titratable groups, and with purified licithin, paperchromatographic spots with Rf-values differing from that for lecithin were obtained. Thus there seems not to be a direct relationship between SA and hydrolysis of connective tissue components apart from a weak lysis of phospholipids.

\section{ATTEMPTS AT PURIFICATION OF THE ACTIVE COMPONENTS IN UDDER EXTRACT}

It appears from the results given in previous sections that UE displays SA which is manifest on both living and dead material. Purification experiments were undertaken to determine whether these effects are associated with one or with several components in the extract.

UE 43 was centrifuged 10 minutes at $10,400 \mathrm{~g}$. 'The precipitate was then suspended in $0.1 \mathrm{M}$ acetate buffer, $\mathrm{pH}$ 6.0, containing $0.15 \mathrm{M}$ sodium chloride. This suspension was tested for $\mathrm{SA}$ in the manner described above. The supernatant was dialysed at $3^{\circ} \mathrm{C}$ against the acetate buffer as above and against distilled water. The contents of the tubes and the dialysis fluids were tested for activity separately and combined. When distilled water 
was used for dialysis, a precipitate was formed in the tube. The precipitate was separated by centrifugation at $4000 \mathrm{~g}$ for 10 minutes then suspended in the acetate buffer and tested for SA. The clear solution remaining after water dialysis and centrifugation was fractionated by salting out at $3^{\circ} \mathrm{C}$ with ammonium sulphate, 1-100 per cent saturation, pH 5.9 (table 4). After being washed twice with ammonium sulphate in the precipitating concentration, the precipitates were resuspended in acetate buffer and tested for SA.

Table 4.

Fractionation of UE with ammonium sulphate, $\mathrm{AmS}, \mathrm{pH} 5.9 \mathrm{t}=+3^{\circ} \mathrm{C}$. Original material: Water dialysed and centrifuged tube contents from UE 43 concentrated as shown in fig. $7 \mathrm{~b}$. dry matter: $0.080 \mathrm{~g}$, activity $1=+, 2=(+), 3=+$.

\begin{tabular}{cccccccc}
\hline $\begin{array}{c}\text { AmS } \\
\text { per cent } \\
\text { saturation }\end{array}$ & Fraction $\begin{array}{c}\text { g precipitate af- } \\
\text { ter centrifugation } \\
10,400 \text { g } 10 \text { min. } \\
\text { and dialysis } \\
\text { against dist. water }\end{array}$ & $\begin{array}{c}\text { per cent } \\
\text { of original } \\
\text { material }\end{array}$ & & & Activity & \\
\hline $\mathbf{1 1 . 0 - 1 2 . 5}$ & 1 & trace & - & $\div$ & $\div$ & $\div$ \\
$\mathbf{2 2 . 0 - 2 5 . 0}$ & 2 & trace & - & $\div$ & $\div$ & $\div$ \\
$\mathbf{3 3 . 0 - 3 7 . 5}$ & $\mathbf{3}$ & $\mathbf{0 . 0 1 4}$ & $\mathbf{1 7 . 5}$ & + & + & $(+)$ \\
$\mathbf{4 4 . 0 - 5 0 . 0}$ & $\mathbf{4}$ & trace & - & $\div$ & $\div$ & $\div$ \\
$\mathbf{5 5 . 0 - 6 2 . 5}$ & $\mathbf{5}$ & $\mathbf{0 . 0 1 2}$ & $\mathbf{1 5 . 0}$ & $(+)$ & $(+)$ & $(+)$ \\
$\mathbf{6 6 . 0 - 7 5 . 0}$ & $\mathbf{6}$ & $\mathbf{0 . 0 0 8}$ & $\mathbf{1 0 . 0}$ & $(+)$ & $\div$ & $\div$ \\
$\mathbf{7 7 . 0 - 8 7 . 5}$ & $\mathbf{7}$ & trace & - & $\div$ & $\div$ & $\div$ \\
$\mathbf{1 0 0 . 0}$ & $\mathbf{8}$ & trace & - & $\div$ & $\div$ & $\div$ \\
\hline
\end{tabular}

Activity: $1=\mathrm{SA} ; 2=\mathrm{VP} ; 3=\mathrm{TL}$

The dry matter content of all precipitates and solutions was established with correction for the weight of the added buffer substances.

The purest active fractions were exposed to paper electrophoresis in veronal buffer, $\mathrm{pH} 8.6$ and $\mu 0.1$, followed by staining with Amido black (19) and fuchsin sulphuric acid (17).

The purest fractions were also studied as 1 per cent solutions in equilibrium with $0.15 \mathrm{M}$ sodium chloride, $\mathrm{pH} 7.0$, by ultracentrifugation.

The results of the purification experiments by centrifugation and dialysis against acetate buffer are summarised in fig. 7 a. Corresponding results for dialysis against distilled water are given in fig. $7 \mathrm{~b}$. Results for salting out can be found in table 
Fi g. 7 a.

The purification of UE 43 .

Dialysis against $0.1 \mathrm{M}$ acetate buffer, $\mathrm{pH}$ 6.0, containing $0.15 \mathrm{M}$ sodium chloride.

Crude extract, dry matter $0.183 \mathrm{~g}$, Activity $1=+, 2=(+), 3=+$.

Centrifuged $10.400 \mathrm{~g}$

for 10 minutes.

Precipitate, dry matter $0.016 \mathrm{~g}$

Supernatant, dry matter $0.165 \mathrm{~g}$,

activity $1=+, 2=+, 3=\div$ activity $1=+, 2=(+), 3=+$

Dialysis, acetate buffer

Tube contents, dry matter

$0.159 \mathrm{~g}$

activity $1=+, 2=(+), 3=+$
Dialysis fluid, dry matter activity $1=\div, 2=\div, 3=\div$

F i g. 7 b.

The purification of UE 43.

Dialysis against distilled water.

Crude extract, dry matter $0.183 \mathrm{~g}$, activity $1=+, 2=(+), 3=+$.

Centrifuged $10.400 \mathrm{~g}$

for 10 minutes

Precipitate, dry matter $0.017 \mathrm{~g}$ activity $1=+, 2=(+), 3=\div$
Supernatant, dry matter $0.162 \mathrm{~g}$, activity $1=+, 2=(+), 3=+$

Dialysis against distilled water

Tube contents (turbid), dry matter $0.126 \mathrm{~g}$ activity $1=+, 2=(+), 3=+$
Dialysis fluid, dry matter activity $1=\div, 2=\div, 3=\div$

Centrifuged $4000 \mathrm{~g}$ for 10 minutes

Precipitate, dry matter $0.0058 \mathrm{~g}$ activity $1=(+), 2=(+), 3=(+)$ $1=\mathrm{SA}: 2=\mathrm{VP} ; 3=\mathrm{TL}$
Supernatant, dry matter $0.080 \mathrm{~g}$ activity $1=+, 2=(+), 3=+$ 
Centrifuged, dialysed

tube contents, per cent
solution, see fig. 7 b.

Staining with Amido black

Fraction 3, prepared as

in tab.4, 1 per cent solu-

tion, $\mathrm{x}$

Fraction 5, prepared as in tab. 4, lper cent solution. $x$

x]
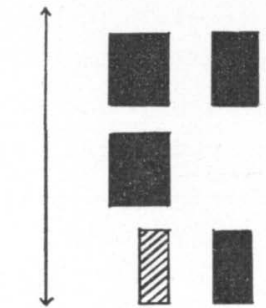

With fuchsin sulphuric acid no staining.

F i g. 8. Schematic representation of electrophoretic results.

Migration time 5 hours.

4, for electrophoresis in fig. 8, and for ultracentrifugation in fig. 9 .

These attempts at purification demonstrate that UE contains at least two non-dialysable fractions of which one produces oedema and can be found in the fraction obtained after centrifugation at $10,400 \mathrm{~g}$ for 10 minutes. The other is mainly concerned with the lysis of connective tissue and is obtained after salting out with ammonium sulphate.

The fraction obtained with 33 to 37.5 per cent saturation, fraction 3 , behaves as a homogeneous substance in paper electrophoresis and ultracentrifugation and has the characteristics of a protein with I. P. $<8.6$. This fraction, however, displays both oedema-producing and connective-tissue-lytic properties. Both these properties seem to be associated with the same fraction since repeated precipitations with ammonium sulphate did not result in separation but only in products with greatly reduced activity.
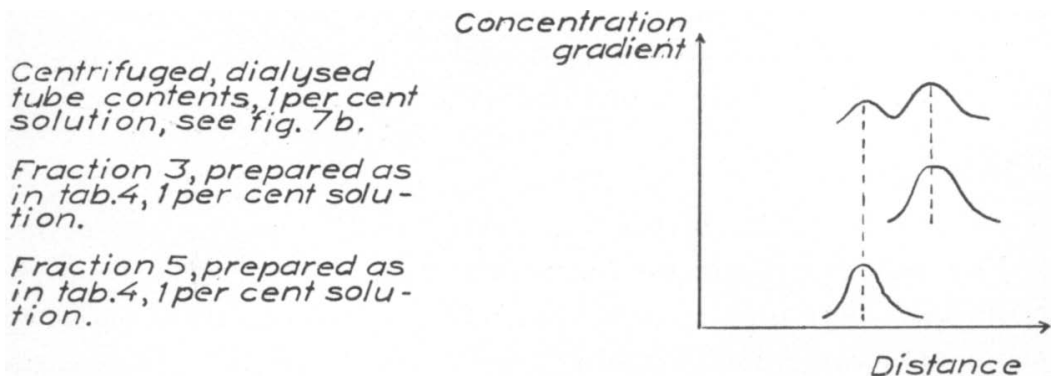

F i g. 9. Schematic representation of results from ultracentrifugation. 52000 r. p. m., 2 hours. 
Another fraction, precipitable between 55.0 and 62.5 per cent saturation, fraction 5 , has properties similar to those of fraction 3. Upon paper electrophoresis it became apparent that this fraction contained two components, one of which in low concentration closely resembles fraction 3 . The oedema-producing and connective-tissue-lytic properties of fraction 5 may depend upon its content of fraction 3 . As in the previous instance, repeating the salting-out procedure gave products with reduced activity.

\section{THE EFFECTS OF UDDER EXTRACT ON MICROORGANISMS}

Substances such as properdin (36) and lysozyme (9) are reported to have antibacterial properties. Hyaluronidase has been shown to exercise a spreading effect on microorganisms $(1,6$, 10). The following studies are concerned with these properties in UE.

Anlibacterial effect.

1) Bacteriostatic effect.

Coagulase-positive Micrococcus aureus isolated from a cow with mastitis was grown in nutrient broth $(32), \mathrm{pH} 7.2 \pm 0.2$, at $37^{\circ} \mathrm{C}$ for 24 hours. The broth was then diluted with $0.15 \mathrm{M}$ sodium chloride until a final concentration corresponding to $\mathbf{1} \times$ $10^{3}$ to $2 \times 10^{3}$ organisms per $0.01 \mathrm{ml}$ was obtained. To tubes containing $0.05 \mathrm{ml}$ bacterial suspension was added $0.5 \mathrm{ml}$ unheated $\mathrm{UE}$ or $\mathrm{UE}$ heated at $100^{\circ} \mathrm{C}$ for 30 minutes. After incubation at $37^{\circ} \mathrm{C}$ for $1,1.5,3,4,5$, and 6 hours $0.1 \mathrm{ml}$ of tube contents was transferred to $15 \mathrm{ml}$ blood agar. The number of organisms corresponding to the various time intervals was estimated after incubation for 24 hours at $37^{\circ} \mathrm{C}$. The results are expressed as increase in organisms after the given time intervals from 0 time.

Similar studies were carried out with Streptococcus agalactiae, also isolated from a mastitic cow.

\section{2) Bacteriolytic effect.}

The bacteriolytic effect was tested in the manner described by Fleming (9). Depressions were cut in the surface of bovine serum and agar plates spread with Micrococcus aureus, Streptococcus agalactiae, Escherichia coli, Pseudomonas aeruginosa, and Micrococcus lysodeiticus. With the exception of the last species, all those organisms were isolated from bovine udders. In the de- 
pressions were placed 0.1 to $0.5 \mathrm{ml}$ unheated and heated UE. The plates were incubated at $37^{\circ} \mathrm{C}$ for 1,2 , and 7 days before the lytic activity of the extracts was evaluated.

The bacteriostatic effect of UE is illustrated in table 5 .

T a b le 5 .

Bacteriostatic effect of UE.

\begin{tabular}{lcccrc}
\hline & \multirow{2}{*}{$\begin{array}{c}\text { time } \\
\text { (hours) }\end{array}$} & \multicolumn{4}{c}{ Increase in organisms } \\
\cline { 3 - 6 } & & unheated 21 & heated & unheated & heated \\
\hline Micr. & 1.0 & $35 \pm 7$ & $16 \pm 10$ & & \\
aureus & 1.5 & & & $610 \pm 79$ & $250 \pm 42$ \\
& 3.0 & $14 \pm 12$ & $66 \pm 13$ & & \\
& 4.0 & & & $1515 \pm 84$ & $1640 \pm 53$ \\
& 5.0 & $1436 \pm 23$ & $2116 \pm 41$ & & \\
Strepto- & 1.5 & & & $2690 \pm 95$ & $5050 \pm 85$ \\
coccus & 4.0 & & & $625 \pm 43$ & $190 \pm 90$ \\
agalactiae & 6.0 & & & $965 \pm 26$ & $1355 \pm 121$ \\
\hline
\end{tabular}

The bacteriostatic effect of UE is weak and is most apparent after incubation for 5 to 6 hours. Increased growth of microorganisms in heated UE than in unheated could depend upon growthpromoting substance or substances being formed during heating or upon growth-inhibiting thermolabile substance or substances.

A bacteriolytic effect could not be demonstrated for UE.

There is, then, no relationship between bacteriolysis and bacteriostasis for UE.

Bacteria-spreading effect.

Rabbits.

The technique described by Dyran-Reynals (6) was utilised in these experiments. Male rabbits weighing about $2.5 \mathrm{~kg}$ and shaved the day preceding the experiment were injected on the right side with unheated UE and on the left with UE heated at $100^{\circ} \mathrm{C}$ for 30 minutes. The first injection was made on the neck, the second at the level of the last ribs, and the third immediately anterior to the pelvis. The method of injection was described above, and the material injected consisted of $0.5 \mathrm{ml}$ unheated or heated UE together with $0.01 \mathrm{ml}$ bacteria suspension. This suspension was obtained by culture of Micrococcus aureus in nu- 
trient broth for 24 hours at $37^{\circ} \mathrm{C}$ and then dilution with unheated or heated UE to the desired concentration.

Two hours after injection the animals were killed and the skin removed and rapidly frozen at $-20^{\circ} \mathrm{C}$. Pieces measuring $0.3 \times 0.3 \mathrm{~cm}$ were excised; the first of these corresponded to the actual point of injection while the other pieces were taken at a distance of 1,3 , and $5 \mathrm{~cm}$ respectively from this point. The excised pieces were ground with $0.1 \mathrm{~g}$ sand and 0.5 to $2 \mathrm{ml} 0.15 \mathrm{M}$ sodium chloride solution. From 0.02 to $0.25 \mathrm{ml}$ of this mixture were transferred to $15 \mathrm{ml}$ blood agar. After incubation at $37^{\circ} \mathrm{C}$ for 24 hours, the number of organisms in each sample was counted and the results calculated to give the number of organisms in each excised skin piece.

Similar experiments were carried out with rabbits kept alive and observed for several days for the inflammatory reactions.

\section{Cattle.}

For these experiments, Micrococcus aureus and UE were injected into udder tissue. A 24-hours culture $-37^{\circ} \mathrm{C}$-was diluted with $0.15 \mathrm{M}$ sodium chloride to give concentrations of 1.4 $\times 10^{6}$ organisms and $1.4 \times 10^{4}$ per $\mathrm{ml}$. The fraction of UE 21 obtained by salting out with ammonium sulphate at 33 to 37.5 per cent saturation was suspended in distilled water and dialysed (dry matter $0.0268 \mathrm{~g}$ per $\mathrm{ml}$ ). In tests on rabbits this fraction had shown SA with Evan's blue. To $2 \mathrm{ml}$ of the purified extract was added $3 \mathrm{ml}$ of the acetate buffer adjusted to $\mathrm{pH} 7.4$ with 0.1 $M$ sodium hydroxide. Unheated and heated $-100^{\circ} \mathrm{C}, 30 \mathrm{minu}-$ tes-UE was injected and to mark the site, $0.5 \mathrm{ml} 1$ per cent Evan's blue in $0.15 \mathrm{M}$ sodium chloride was used. These solutions had a $\mathrm{pH}$ of $7.4 \pm 0.2$ and were injected at the rate mentioned previously into the base of the teat to avoid injection into the milk ducts. Into the right anterior quarter was injected $1 \mathrm{ml}$ heated UE, $1 \mathrm{ml}$ bacteria suspension, and $0.5 \mathrm{ml}$ Evan's blue. The right posterior quarter was injected with $1 \mathrm{ml}$ unheated UE, $1 \mathrm{ml} 0.15 \mathrm{M}$ sodium chloride, and $0.5 \mathrm{ml}$ Evan's blue. The left posterior quarter was injected with $1 \mathrm{ml}$ acetate buffer, $1 \mathrm{ml}$ bacteria suspension, and $0.5 \mathrm{ml}$ Evan's blue. And finally, the left anterior quarter was injected with $1 \mathrm{ml}$ unheated UE, $1 \mathrm{ml}$ bacteria suspension, and $0.5 \mathrm{ml}$ Evan's blue. The udder was examined on each of the next 3 days and the animal was slaughtered on the third. Pieces of tissue $0.5 \times 0.5 \mathrm{~cm}$ were taken at the site of 
injection and 1, 3, 5, and $9 \mathrm{~cm}$ from this point. After grinding with $1 \mathrm{ml} 0.15 \mathrm{M}$ sodium chloride in a Potter-Elvehjem homogenizer, the tissue samples were examined for the number of $\mathrm{Mi}$ crococcus aureus.

Fig. 10 represents a typical example of bacterial spreading in rabbit skin showing that $\mathrm{UE}$ has a similar spreading activity for microorganisms and Evan's blue.

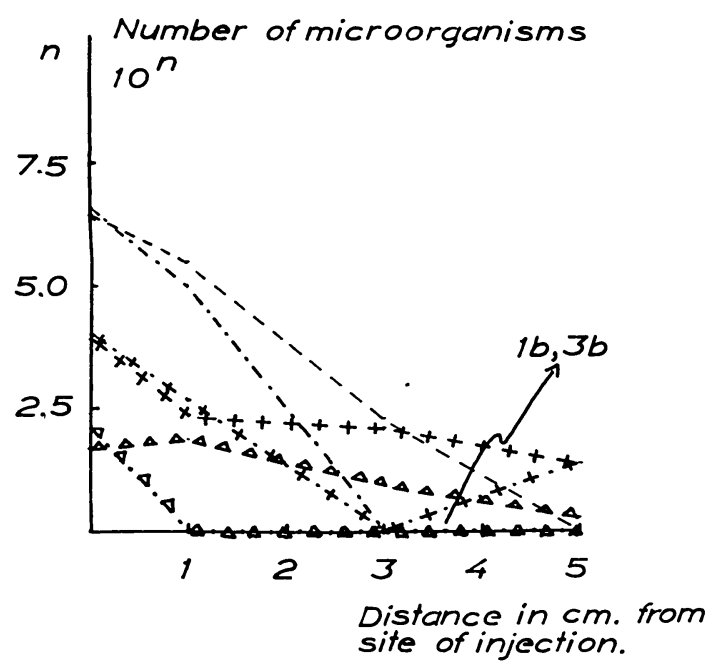

F i g. 10.

Spreading activity of udder extract on microbes after 2 hours. Symbols: $1 \mathrm{a},-\longrightarrow$ UE 19 and $1 \times 10^{9}$ organisms; $1 \mathrm{~b}, \ldots \cdot-$ UE 19 , heated, and $1 \times 10^{9}$ organisms; $2 \mathrm{a}$, $+++\mathrm{UE} 19$ and $4 \times 10^{5}$ organisms; $2 \mathrm{~b}$, $+\cdot+$ UE 19, heated, and $4 \times 10^{5}$ organisms; 3 a, $\Delta \Delta \triangle$ UE 19 and $2 \times 10^{2}$ organisms; $3 \mathrm{~b}, \Delta \cdot \triangle \mathrm{UE} 19$, heated, and $2 \times 10^{2}$ organisms.

During the rabbit experiments with observation of the inflammatory reactions it was noticed that 2 days after injection, the greater dose, $10^{\circ}$ organisms, gave a more pronounced and extensive inflammatory reaction for unheated than for the heated extract. At the lower dose, $2 \times 10^{2}$ organisms, the reverse was the case.

The results obtained for cattle were similar to those for rabbits.

It appears, then, that the local injection of microorganisms and $\mathrm{UE}$ in vivo gives results which resemble those described by Duran-Reynals (6) and Pijoan (29). The results for SA of UE obtained cannot be considered fully comparable with those de- 
monstrated by these investigators since they worked with testicular extract-hyaluronidase--and no hydrolytic activity for hyaluronic acid has been demonstrated for UE.

The bacterial spreading effect demonstrated for UE can apparently be ascribed to the VP-increasing and weak phospholipidlytic effect shown.

\section{Acknowledgement.}

The writers would like to thank Professors D. T. Berman and J. W. Williams, Madison, Docent $C$. Weibull and Docent S. Gardell, Stockholm, and Dr. B. Högberg, Hälsingborg, for their much appreciated help.

These studies, carried out during 1955 and 1956 at the University of Wisconsin and during 1957 to 1959 at the Royal Veterinary College, Stockholm, have been supported by "anslaget till främjande av veterinärmedicinsk forskning”, "Sverige-Amerika Stiftelsen", American Association of University Women, and "Jordbrukets forskningsråd".

\section{REFERENCES}

1. Asboe-Hansen, G.: Connective Tissue in Health and Disease, Copenhagen, 1954, 103, 208.

2. Bamann, E. \& K. Myrbäck: Methoden der Fermentforschung, Leipzig, 1941, 1687.

3. Becker, E. L., D. L. Wilhelm \& A. A. Miles: Nature (London), 1959, $183,1264$.

4. Christensen, L. K.: Compt. rend. trav. lab. Carlsberg. Sér. chim. 1952, 28, 37.

5. Conway, E. J.: Microdiffusion Analyses and Volymetric Error, London, 1950, 127.

6. Duran-Reynals, F.: J. Exp. Med., New York, 1935, 61, 617.

7. Elliott, J. R. \& C. W. Turner: Univ. Missouri, College Agriculture, Agric. Exp. Sta., Research Bull., 1953, 537, 1.

8. Feldberg, W. \& M. Schachter: J. Physiol. (London) 1952, 118, 124.

9. Fleming, A.: Lancet 1929, 217.

10. Furness, F. N.: Ann. N.Y. Acad. Sci. 1956, 65, 57.

11. Glick, D.: Methods of Biochemical Analyses, New York, 1956, 3, 62.

12. Hawk, P. B., B. L. Oser \& W. H. Summerson: Practical Physiological Chemistry, New York, Toronto 1953, 363.

13. Hayes, M. A. \& T. G. Reed: Proc. Soc. Exp. Biol. Med. 1950, 75, 357.

14. Highberger, J. H.: J. Am. Leather Chemists' Assoc. 1936, 31, 93.

15. Hoover, C. R. \& C. W. Turner: Univ. Missouri, College Agriculture, Agric. Exp. Sta., Research Bull. 1954, 563, 1. 
16. Huenekens, F. M., D. J. Hanahan \& M. Uziel: J. Biol. Chem. 1954, $206,443$.

17. Laurell, H.: Scand. J. Clin. Lab. Invest. 1956, 8, 21.

18. Levine, C. \& E. Chargaff: J. Biol. Chem. 1951, 192, 465.

19. LKB fabriksaktiebolag, Stockholm: Paper electrophoretic Equipment.

20. Madinaveitia, J.: Biochem. J. 1938, 32, 1806.

21. Madinaveitia, J.: Biochem. J. 1939, 33, 347.

22. Mc Clean, D.: J. Pathol. and Bacteriol. 1931, 34, 459.

23. Menkin, V.: Dynamics of Inflammation, New York, 1950.

24. Meyer, K.: Physiol. Revs. 1947, 27, 335.

25. Miner, R. W. \& W. Briggs: Ann. N.Y. Acad. Sci. 1950, 52, 1028.

26. Neumann, R. E. \& A. A. Tytell: Proc. Soc. Exp. Biol. Med. 1950, $73,409$.

27. Norton, S.: Brit. J. Pharmacol. 1954, 9. 494.

28. Pangborn, M. C.: J. Biol. Chem. 1951, 188, 471.

29. Pijoan, M.: J. Exp. Med. 1931, 53, 37.

30. Rocha e Silva, M. \& C. A. Dragstedt: J. Pharmacol. Exp. Therap. $1941,73,405$.

31. Rothman, S.: Physiology and Biochemistry of the Skin. Chicago, 1954, 391.

32. Soc. American Bacteriologists: Manual of Microbiological Methods. New York, Toronto, London, 1957.

33. Somogyi, M.: J. Biol. Chem. 1945, 160, 61, 69.

34. Spector, W. G.: Pharmacol. Rev. 1958, 10, 475.

35. Weidenhagen, R.: Ergebnisse der Enzymforschung 1954, 13, 31.

36. Whitelock, O. v. St., \& F. N. Furness: Ann. N.Y. Acad. Sci. 1956, $66,233$.

\section{SUMMARY}

Spreading activity for bovine udder extract has been demonstrated by the intradermal injection of the extract together with Evan's blue into rabbit skin. This activity is not species specific and is most evident in extracts obtained from pregnant cattle.

This spreading activity is associated with a component or components in the extract, probably protein in nature, which increase vascular permeability and lyse connective tissue.

Udder extract also exercises a spreading effect on microorganisms. Its antibacterial effect is weak.

\section{ZUSAMMENFASSUNG}

Ausbreitungsaktivität von boviner Euterextrakt.

Am Kaninchen wurde durch intradermale Injektion von Euterextrakt von Kuh zusammen mit Evan's blue eine Ausbreitungsaktivität demonstriert. Diese Aktivität ist nicht artspezifisch. Sie ist am meisten ausgeprägt bei Extrakten von schwangeren Kühen. 
Diese Ausbreitungsaktivität ist an eine Komponente, oder mehrere Komponenten, wahrscheinlich von Eiweissnatur, gebunden. Diese beeinflusst (oder beeinflussen) die Permeabilität der Gefässe und spaltet (oder spalten) Bindegewebe.

Euterextrakt übt auch einen Ausbreitungseffekt auf Mikroorganismen aus. Die antibakterielle Wirkung is wenig ausgeprägt.

\section{SAMMANFATTNING}

Spridningseffëkt av juverextrakt från nöt.

I juverextrakt från nöt har en spridande verkan visats vid intradermal injektion av extrakt tillsammans med Evan's blue. Denna, icke artbundna, verkan synes mest utpräglad i extrakt från dräktiga djur.

Den funna spridningsverkan är till synes bunden vid komponent(er) av proteinnatur, som ökar kärlpermeabiliteten och spjälkar bindväv.

Juverextrakt äger spridande verkan på mikrober. Dess antibakteriella verkan är svag. 